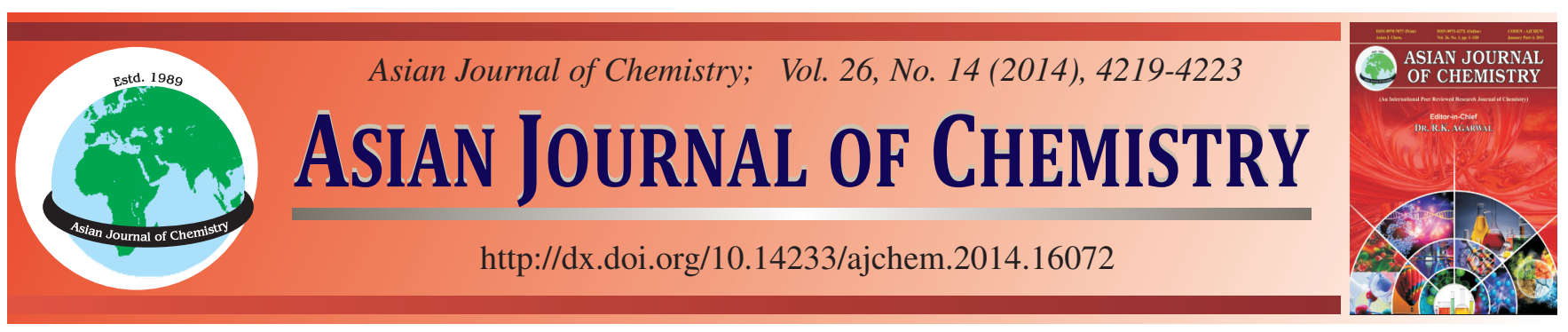

\title{
River Odra Estuary (North-West Poland): Assessment of Physical and Chemical Parameters of Water on Basis of European Union Water Framework Directive
}

\author{
PIOTR DANISZEWSKI
}

Faculty of Biology Department of Invertebrate Zoology and Limnology, University of Szczecin, 13 Waska Street, 71-415 Szczecin, Poland Corresponding author: E-mail: daniszewski73@gmail.com

\begin{abstract}
This paper presents the evaluation of physico-chemical parameters of water river Odra Estuary based on the European union water framework directive. Water is a necessary element for endurance of living on earth, which contains minerals, essential for human being as well as for earth and aquatic life. Lakes have long been at the center of human attention. To address the increasing degradation of surface waters in the European union, the approach to the evaluation and protection of water resources was changed. This approach was formulated in the European union water framework directive (2000/60/EC), which calls for the protection of water, as well as an environmentfriendly and comprehensive approach to water assessment. The Odra Estuary includes, as its major part, the brackish Szczecin Lagoon which consists of two parts: the Kleines Haff (located in Germany) and the Wielki Zalew located in Poland. The Lagoon receives the river Odra water supplied from the south; prior to being discharged into the Lagoon, part of the Odra flow passes through Lake Dabie. The Odra (German: Oder) estuary is located at the southern Baltic sea (German-Polish border). It consists of the Szczecin Lagoon and the Pomeranian Bay. The Szczecin Lagoon $\left(687 \mathrm{~km}^{2}\right)$ can be subdivided into the "Large Lagoon" (Polish: Wielki Zalew) on the polish territory and the "Small Lagoon" (German: Kleines Haff) on the German side. The Lagoon is connected to the Pomeranian Bay via 3 outlets. The research was carried out in the years 2008-2012, between april and october. From each of the three measuring stations located in the water river Odra estuary included the study, two separate water samples were taken for chemical analysis. The studied water river Odra Estuary had $\mathrm{pH}$ values in the neutral range 7.76 to 7.89. According to the classification of the European union water framework directive, all water were classified as first class. The tests have demonstrated that water quality in the water Szczecin Lagoon with regard to the tested indicators varied. By analyzing the average annual values, one can note that the $\mathrm{pH}, \mathrm{O}_{2 \text { diss }}$ and $\mathrm{NO}_{3}{ }^{-}$concentration showed a relatively small variation in all the investigated water. The total suspended solids in the river Odra Estuary, fell into the II class. The $\mathrm{P}_{\text {tot. }}$. concentrations in the surface layer of the water river Odra estuary was little differentiated, reaching the levels appropriate for the III quality class according to the classification of the European union water framework directive. The total phosphorus concentration was 0.48-0.69 mgP dm${ }^{-3}$. The concentrations of $\mathrm{PO}_{4}{ }^{3-}$ diss in the tested waters varied more significantly-corresponding to water quality classes ranging from IV. The concentrations saturation with $\mathrm{O}_{2}$ was 42.9-96.3\%. In the case of nitrogen compounds, nitrates and nitrites values for these indicators fell into the I and II class in all the surveyed water river Odra Estuary in accordance with the classification of the European union water framework directive. The indicator which proves high productivity of the water is the biochemical oxygen demand $\left(\mathrm{BOD}_{5}\right)$. The level of this indicator in the studied river Odra estuary was at level III. The highest concentration of oxygen in the waters was found in the river Odra Estuary (about $8.3 \mathrm{mg} \mathrm{O}_{2} \mathrm{dm}^{-3}$ ). In the remaining water oxygen levels were similar (still in I class). National sanitation foundation water quality index (NSF WQI) used for rating of water quality in river Odra estuary indicates that the quality of water is slightly polluted $(\mathrm{WQI}=51.4)$.
\end{abstract}

Keywords: Water, River Odra Estuary, Chemical and physico-chemical indicators, Water quality index.

L- -

\section{INTRODUCTION}

Water is a necessary element for endurance of living on earth, which contains minerals, essential for humans as well as for earth and aquatic life. Lakes have long been at the center of human attention ${ }^{1-8}$. Several cities, industrial infrastructures and agriculture complexes have been built up in vicinity of rivers and other water bodies. Development of human communities and increase in irresponsible use of water resources has

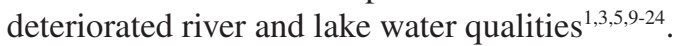

Population growth and pollution caused by toxic waste water, surface water runoffs from municipal, industrial and agricultural sources have increased pollution load and further limited healthy water resources ${ }^{18}$ and surface water quality management. Bearing the idea in mind it is inevitable to understand quality of surface water for various purposes such as use for drinking, industries and agriculture ${ }^{5-8}$. Knowledge on point sources of pollution and pollutants in the region are prerequisite for appropriate use of water. Monitoring and 
control of surface water is critical to guaranty high quality

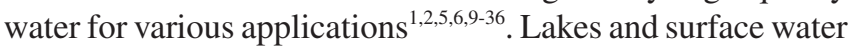
reservoirs are the planet's most important freshwater resources and provide numerous benefits ${ }^{1,2,5,6,9-16,25-36}$. They are used for domestic and irrigation purposes and provide ecosystems for aquatic life especially fish, in that way functioning as a source of essential protein and for significant elements of the world's biological diversity ${ }^{1,2,5,6,9-14,17-24,37,38}$. They have important social and economic benefits as a result of tourism and recreation and are culturally and aesthetically important for people throughout the world. They also play an equally important role in flood control ${ }^{5,10-24,27-30,36}$.

Evaluation of the quality of the structure and the functioning of aquatic ecosystems, by comparing the status of the existing undisturbed conditions expected in status (reference), is a requirement for monitoring and evaluation systems of classification by the European directive 2000/60/EC, known as the European Union Water Framework Directive ${ }^{1-8}$. With this in mind, it is an important issue to properly protect water reservoirs and also take action to counter the adverse effects of human activities on the natural environment, including water bodies $^{2,5,9-25,27-30,36}$.

The ecological status of surface waters and groundwater is assessed on the basis of the ecological potential of the biological and physico-chemical and hydromorphological indicators ${ }^{4,11-18,21-25,28,32,33,37-41}$.

The goal of the water framework directive is to achieve good water status in all the member states of the European Union $^{1,3,5,7,9,10,32,40,42}$.

This paper presents the evaluation of physico-chemical parameters of water in the Szczecin Lagoon based on the European Union water framework directive.

\section{EXPERIMENTAL}

The Odra Estuary includes, as its major part, the brackish Szczecin Lagoon which consists of two parts: the Kleines Haff (located in Germany) and the Wielki Zalew located in Poland (Fig. 1). The Lagoon receives the river Odra water supplied from the south; prior to being discharged into the Lagoon, part of the Odra flow passes through lake Dabie $e^{43,14,15}$. In its northern part, the Lagoon connects-via three straits (the Peene, Swina and Dziwna)-with the Pomeranian Bay, a Baltic embayment ${ }^{14,15,43}$.

The Odra (German: Oder) estuary is located at the southern Baltic Sea (German-Polish border). It consists of the Szczecin (Oder-) Lagoon and the Pomeranian Bay. The Szczecin Lagoon $\left(687 \mathrm{~km}^{2}\right)$ can be subdivided into the "Large Lagoon" (Polish: Wielki Zalew) on the Polish territory and the "Small Lagoon" (German: Kleines Haff) on the German side. The Lagoon is connected to the Pomeranian Bay via 3 outlets ${ }^{14,15,43}$.

The entire estuary is dominated by the discharge of the river Odra (Oder) into the Lagoon. With its length of $854 \mathrm{~km}$ and basin area of $120,000 \mathrm{~km}^{2}$, the Odra is one of the most important rivers in the Baltic region. The average annual Odra discharge is $17 \mathrm{~km}^{3}\left(530 \mathrm{~m}^{3} \mathrm{~s} \mathrm{1}\right)$ and it contributes at least $94 \%$ to the lagoon's water budget ${ }^{11-15,43}$.

The research was carried out in the years 2008-2012, between April and October. From each of the three measuring

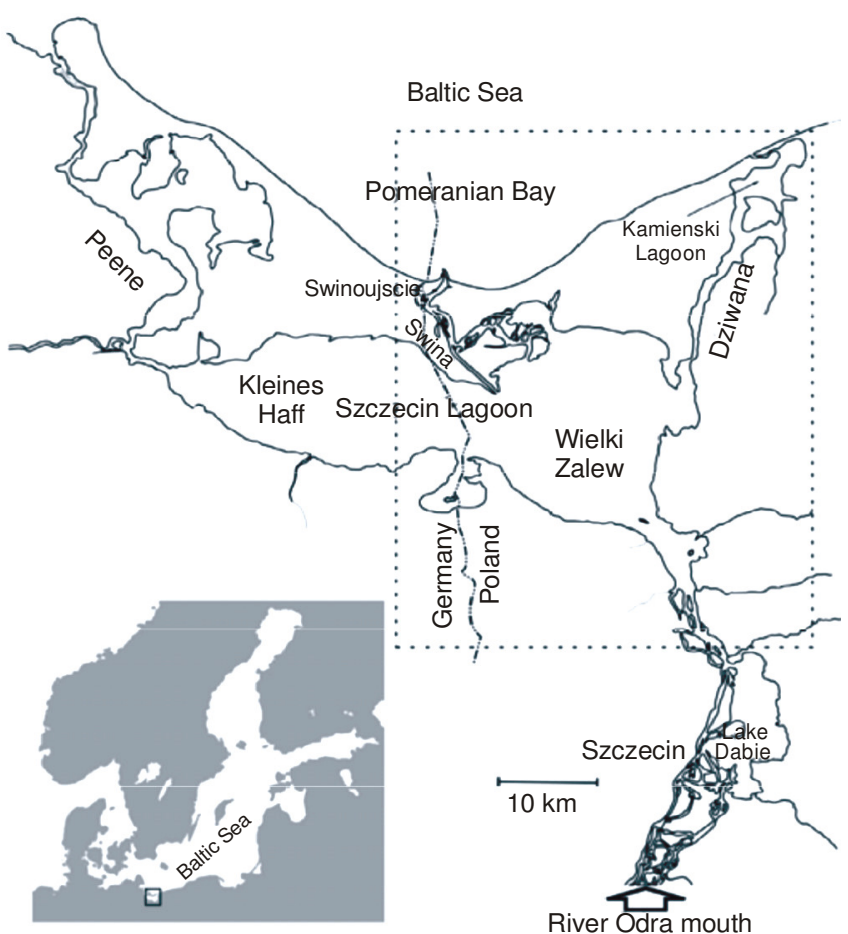

Fig. 1. River Odra Estuary and sampling figure sites location

stations located in the water Szczecin Lagoon included the study, two separate water samples were taken for chemical analysis.

Upon sampling, the water $\mathrm{pH}$ was measured. Water was tested in compliance with the Polish Standards. Collected water samples were stabilized pursuant to the guidelines of the Polish Standards ${ }^{1-5,27}$. Other indicators of water quality were marked within $24 \mathrm{~h}$ of sampling. The oxidation of dissolved organic matter was measured with the COD-Mn method, in accordance with Polish Standards ${ }^{1-5,27}$.

Dissolved oxygen was marked in accordance with the methodology described by Winkler in Daniszewski's work $^{1-4,27}$. The degree of water oxygenation was specified by arrays described by Nemerow ${ }^{7}$. The levels of total suspended solids, $\mathrm{BOD}_{5}, \mathrm{NH}_{4}^{+}, \mathrm{NO}_{2}^{-}, \mathrm{NO}_{3}^{-}, \mathrm{PO}_{43}^{-}$diss and $\mathrm{P}_{\text {tot. }}$. were marked-in accordance with the methodology described by Daniszewski ${ }^{1-5,27}$.

The quality objectives were evaluated according to the criteria recommended for assessing inland surface waters as set out in the European Union Water Framework Directive (Directive 2000/60/EC).

\section{RESULTS AND DISCUSSION}

The results for the River Odra Estuary, along with the classification in accordance with the European Union Water Framework Directive are presented in Table-1.

The $\mathrm{pH}$ of the water in the water River Odra Estuary is influenced by the physico-chemical and biotic interactions of environmental factors ${ }^{1-5,9,26,28-30,42}$.

Among others, the degree of acidity directly affects life processes occurring in ecosystems. It is responsible for the correct uptake of nutrients by organisms. High alkalinity is beneficial for assimilation and therefore, the nitrogen and phosphorus compounds found in water are much more accessible 


\begin{tabular}{|c|c|c|c|c|}
\hline \multicolumn{5}{|c|}{$\begin{array}{c}\text { TABLE-1 } \\
\text { QUALITY OF SURFACE WATER OF RIVER ODRA ESTUARY } \\
\text { (SPRING, SUMMER AND AUTUMN } 2008 \text { - 2012) ALONG WITH } \\
\text { THE CLASSIFICATION VALUES OF INDICATORS ACCORDING } \\
\text { TO THE CRITERIA OF THE EUROPEAN UNION WATER } \\
\text { FRAMEWORK DIRECTIVE (2000/60/EC) }\end{array}$} \\
\hline \multicolumn{5}{|c|}{ River Odra Estuary } \\
\hline \multicolumn{5}{|c|}{2008 year } \\
\hline No & Water quality indices units & $\begin{array}{c}17.04 .2008 \\
\text { Spring } \\
\end{array}$ & $\begin{array}{c}24.07 .2008 \\
\text { Summer }\end{array}$ & $\begin{array}{c}15.10 .2008 \\
\text { Autumn }\end{array}$ \\
\hline 1. & $\begin{array}{l}\text { Total suspended solids } \\
\left(\mathrm{mg} \mathrm{O}_{2} \cdot \mathrm{dm}^{-3}\right)\end{array}$ & 22.5 (II) & 23.7 (II) & 21.4 (II) \\
\hline 2. & $\mathrm{pH}(-)$ & 7.84 (I) & 7.89 (I) & 7.87 (I) \\
\hline 3. & COD-Mn $\left(\mathrm{mg} \mathrm{O}_{2} \mathrm{dm}^{-3}\right)$ & 7.5 (III) & 8.6 (III) & 8.2 (III) \\
\hline 4. & $\mathrm{BOD}_{5}\left(\mathrm{mg} \mathrm{O}_{2} \mathrm{dm}^{-3}\right)$ & 5.4 (III) & 5.8 (III) & 5.7 (III) \\
\hline 5. & $\mathrm{O}_{2 \text { diss }}\left(\mathrm{mg} \mathrm{O}_{2} \mathrm{dm}^{-3}\right)$ & 7.1 (I) & 7.7 (I) & 7.3 (I) \\
\hline 6. & $\mathrm{NO}_{3}^{-}\left(\mathrm{mg} \mathrm{N}^{-1} \mathrm{dm}^{-3}\right)$ & 0.34 (I) & 0.38 (I) & 0.36 (I) \\
\hline 7. & $\mathrm{NO}_{2}^{-}\left(\mathrm{mg} \mathrm{N} \cdot \mathrm{dm}^{-3}\right)$ & 0.033 (II) & 0.038 (II) & 0.035 (II) \\
\hline 8. & $\mathrm{NH}_{4}^{+}\left(\mathrm{mg} \mathrm{N}^{-1 m^{-3}}\right)$ & 0.68 (II) & 0.78 (II) & 0.69 (II) \\
\hline 9. & $\mathrm{PO}_{4}^{3-}$ diss $\left(\mathrm{mg} \mathrm{PO}_{4} \mathrm{dm}^{-3}\right)$ & 0.77 (IV) & 0.83 (IV) & 0.71 (IV) \\
\hline 10. & $P_{\text {tot. }}\left(\mathrm{mg} \mathrm{P} \cdot \mathrm{dm}^{-3}\right)$ & 0.48 (III) & 0.58 (III) & 0.52 (III) \\
\hline 11. & Saturation with $\mathrm{O}_{2}(\%)$ & $51.7(-)$ & $87.3(-)$ & $45.1(-)$ \\
\hline 12. & $\begin{array}{l}\text { Residue after ignition } \\
\left(\mathrm{mg} \cdot \mathrm{dm}^{-3}\right)\end{array}$ & $185(-)$ & $212(-)$ & $193(-)$ \\
\hline \multicolumn{5}{|c|}{2009 year } \\
\hline No & $\begin{array}{l}\text { Water quality } \\
\text { indices units }\end{array}$ & $\begin{array}{c}15.04 .2009 \\
\text { Spring } \\
\end{array}$ & $\begin{array}{c}22.07 .2009 \\
\text { Summer }\end{array}$ & $\begin{array}{c}21.10 .2009 \\
\text { Autumn }\end{array}$ \\
\hline 1. & $\begin{array}{l}\text { Total suspended solids } \\
\left(\mathrm{mg} \mathrm{O}_{2} \cdot \mathrm{dm}^{-3}\right)\end{array}$ & 20.7 (II) & 22.3 (II) & 20.9 (II) \\
\hline 2. & $\mathrm{pH}(-)$ & 7.79 (I) & 7.85 (I) & 7.76 (I) \\
\hline 3. & COD-Mn $\left(\mathrm{mg} \mathrm{O}_{2} \cdot \mathrm{dm}^{-3}\right)$ & 7.2 (III) & 7.4 (III) & 7.6 (III) \\
\hline 4. & $\mathrm{BOD}_{5}\left(\mathrm{mg} \mathrm{O}_{2} \cdot \mathrm{dm}^{-3}\right)$ & 5.3 (III) & 5.4 (III) & 5.1 (III) \\
\hline 5. & $\mathrm{O}_{2 \text { diss }}\left(\mathrm{mg} \mathrm{O}_{2} \mathrm{dm}^{-3}\right)$ & 7.3 (I) & 7.4 (I) & 7.1 (I) \\
\hline 6. & $\mathrm{NO}_{3}{ }^{-}\left(\mathrm{mg} \mathrm{N}^{-} \mathrm{dm}^{-3}\right)$ & 0.34 (I) & 0.38 (I) & 0.36 (I) \\
\hline 7. & $\mathrm{NO}_{2}^{-}\left(\mathrm{mg} \mathrm{N} \cdot \mathrm{dm}^{-3}\right)$ & 0.034 (II) & 0.037 (II) & 0.035 (II) \\
\hline 8. & $\mathrm{NH}_{4}^{+}\left(\mathrm{mg} \mathrm{N}^{-\mathrm{dm}^{-3}}\right)$ & 0.77 (II) & 0.86 (II) & 0.71 (II) \\
\hline 9. & $\mathrm{PO}_{4}^{3-}$ diss $\left(\mathrm{mg} \mathrm{PO}_{4} \mathrm{dm}^{-3}\right)$ & 0.75 (IV) & 0.81 (IV) & 0.78 (IV) \\
\hline 10. & $\mathrm{P}_{\text {tot. }}\left(\mathrm{mg} \mathrm{P} \cdot \mathrm{dm}^{-3}\right)$ & 0.63 (III) & 0.68 (III) & 0.58 (III) \\
\hline 11. & Saturation with $\mathrm{O}_{2}(\%)$ & $51.6(-)$ & $82.9(-)$ & $48.6(-)$ \\
\hline 12. & $\begin{array}{l}\text { Residue after ignition } \\
\left(\mathrm{mg}^{-3} \mathrm{dm}^{-3}\right)\end{array}$ & $189(-)$ & $196(-)$ & $181(-)$ \\
\hline \multicolumn{5}{|c|}{2010 year } \\
\hline No & $\begin{array}{l}\text { Water quality } \\
\text { Indices units }\end{array}$ & $\begin{array}{l}21.04 .2010 \\
\text { Spring }\end{array}$ & $\begin{array}{l}14.07 .2010 \\
\text { Summer }\end{array}$ & $\begin{array}{c}20.10 .2010 \\
\text { Autumn }\end{array}$ \\
\hline 1. & $\begin{array}{l}\text { Total suspended solids } \\
\left(\mathrm{mg} \mathrm{O}_{2} \mathrm{dm}^{-3}\right)\end{array}$ & 21.8 (II) & 22.9 (II) & 20.7 (II) \\
\hline 2. & $\mathrm{pH}(-)$ & 7.74 (I) & 7.81 (I) & 7.85 (I) \\
\hline 3. & COD-Mn $\left(\mathrm{mg} \mathrm{O}_{2} \cdot \mathrm{dm}^{-3}\right)$ & 7.4 (III) & 7.7 (III) & 7.6 (III) \\
\hline 4. & $\mathrm{BOD}_{5}\left(\mathrm{mg} \mathrm{O}_{2} \mathrm{dm}^{-3}\right)$ & 5.4 (III) & 5.6 (III) & 5.2 (III) \\
\hline 5. & $\mathrm{O}_{2 \text { diss }}\left(\mathrm{mg} \mathrm{O}_{2} \mathrm{dm}^{-3}\right)$ & 7.3 (I) & 7.7 (I) & 7.2 (I) \\
\hline 6. & $\mathrm{NO}_{3}{ }^{-}\left(\mathrm{mg} \mathrm{N} \cdot \mathrm{dm}^{-3}\right)$ & $0.32(\mathrm{I})$ & 0.39 (I) & 0.34 (I) \\
\hline 7. & $\mathrm{NO}_{2}^{-}\left(\mathrm{mg} \mathrm{N}^{-\mathrm{dm}^{-3}}\right)$ & 0.034 (II) & 0.038 (II) & 0.037 (II) \\
\hline 8. & $\mathrm{NH}_{4}^{+}\left(\mathrm{mg} \mathrm{N}^{-1 \mathrm{dm}^{-3}}\right)$ & 0.77 (II) & 0.84 (II) & 0.79 (II) \\
\hline 9. & $\mathrm{PO}_{4}^{3-}$ diss $\left(\mathrm{mg} \mathrm{PO}_{4} \cdot \mathrm{dm}^{-3}\right)$ & 0.77 (IV) & 0.87 (IV) & 0.77 (IV) \\
\hline 10. & $\mathrm{P}_{\text {tot. }}\left(\mathrm{mg} \mathrm{P} \cdot \mathrm{dm}^{-3}\right)$ & 0.59 (III) & 0.69 (III) & 0.57 (III) \\
\hline 11. & Saturation with $\mathrm{O}_{2}(\%)$ & $54.9(-)$ & $89.2(-)$ & $45.8(-)$ \\
\hline 12. & $\begin{array}{l}\text { Residue after ignition } \\
\left(\mathrm{mg} \cdot \mathrm{dm}^{-3}\right)\end{array}$ & $182(-)$ & $194(-)$ & $175(-)$ \\
\hline \multicolumn{5}{|c|}{2011 year } \\
\hline No & $\begin{array}{l}\text { Water quality } \\
\text { indices units }\end{array}$ & $\begin{array}{l}20.04 .2011 \\
\text { Spring }\end{array}$ & $\begin{array}{l}20.07 .2011 \\
\text { Summer }\end{array}$ & $\begin{array}{l}19.10 .2011 \\
\text { Autumn }\end{array}$ \\
\hline 1. & $\begin{array}{l}\text { Total suspended solids } \\
\left(\mathrm{mg} \mathrm{O}_{2} \mathrm{dm}^{-3}\right)\end{array}$ & 21.3 (II) & 22.4 (II) & 21.9 (II) \\
\hline 2. & $\mathrm{pH}(-)$ & 7.82 (I) & 7.89 (I) & 7.76 (I) \\
\hline 3. & COD-Mn $\left(\mathrm{mg} \mathrm{O}_{2} \cdot \mathrm{dm}^{-3}\right)$ & 7.7 (III) & 8.2 (III) & 8.0 (III) \\
\hline 4. & $\mathrm{BOD}_{5}\left(\mathrm{mg} \mathrm{O}_{2} \cdot \mathrm{dm}^{-3}\right)$ & 5.1 (III) & 5.7 (III) & 4.8 (III) \\
\hline 5. & $\mathrm{O}_{2 \text { diss }}\left(\mathrm{mg} \mathrm{O}_{2} \mathrm{dm}^{-3}\right)$ & 7.3 (I) & 8.1 (I) & 7.4 (I) \\
\hline 6. & $\mathrm{NO}_{3}-\left(\mathrm{mg} \mathrm{N} \cdot \mathrm{dm}^{-3}\right)$ & 0.47 (I) & 0.57 (I) & 0.46 (I) \\
\hline 7. & $\mathrm{NO}_{2}^{-}\left(\mathrm{mg} \mathrm{N}^{-\mathrm{dm}^{-3}}\right)$ & 0.032 (II) & 0.042 (II) & 0.036 (II) \\
\hline 8. & $\mathrm{NH}_{4}^{+}\left(\mathrm{mg} \mathrm{N} \cdot \mathrm{dm}^{-3}\right)$ & 0.75 (II) & 0.81 (II) & 0.73 (II) \\
\hline 9. & $\mathrm{PO}_{4}{ }^{3-}$ diss $\left(\mathrm{mg} \mathrm{PO}_{4} \mathrm{dm}^{-3}\right)$ & 0.74 (IV) & 0.78 (IV) & 0.74 (IV) \\
\hline 10. & $\mathrm{P}_{\text {tot. }}\left(\mathrm{mg} \mathrm{P} \cdot \mathrm{dm}^{-3}\right)$ & 0.58 (III) & 0.65 (III) & 0.53 (III) \\
\hline 11. & Saturation with $\mathrm{O}_{2}(\%)$ & $62.9(-)$ & $88.1(-)$ & $47.2(-)$ \\
\hline 12. & $\begin{array}{l}\text { Residue after ignition } \\
\left(\mathrm{mg} \cdot \mathrm{dm}^{-3}\right)\end{array}$ & $185(-)$ & $216(-)$ & $188(-)$ \\
\hline
\end{tabular}

\begin{tabular}{|c|c|c|c|c|}
\hline \multicolumn{5}{|c|}{2012 year } \\
\hline No & Water quality indices & Units & $\begin{array}{l}18.04 .2012 \\
\text { Spring }\end{array}$ & $\begin{array}{c}18.07 .2012 \\
\text { Summer }\end{array}$ \\
\hline 1. & $\begin{array}{l}\text { Total suspended solids } \\
\left(\mathrm{mg} \mathrm{O}_{2} \cdot \mathrm{dm}^{-3}\right)\end{array}$ & 22.1 (II) & 23.6 (II) & 20.9 (II) \\
\hline 2. & $\mathrm{pH}(-)$ & 7.79 (I) & 7.81 (I) & $7.76(\mathrm{I})$ \\
\hline 3. & $\operatorname{COD}-\mathrm{Mn}\left(\mathrm{mg} \mathrm{O}_{2} \mathrm{dm}^{-3}\right)$ & 8.0 (III) & 8.5 (III) & 7.7 (III) \\
\hline 4. & $\mathrm{BOD}_{5}\left(\mathrm{mg} \mathrm{O}_{2} \mathrm{dm}^{-3}\right)$ & 4.8 (III) & 5.8 (III) & 5.2 (III) \\
\hline 5. & $\mathrm{O}_{2 \text { diss }}\left(\mathrm{mg} \mathrm{O}_{2} \mathrm{dm}^{-3}\right)$ & 8.1 (I) & 8.3 (I) & $7.5(\mathrm{I})$ \\
\hline 6. & $\mathrm{NO}_{3}^{-}\left(\mathrm{mg} \mathrm{N} \cdot \mathrm{dm}^{-3}\right)$ & 0.49 (I) & $0.58(\mathrm{I})$ & 0.46 (I) \\
\hline 7. & $\mathrm{NO}_{2}^{-}\left(\mathrm{mg} \mathrm{N}^{-3} \mathrm{dm}^{-3}\right)$ & 0.034 (II) & 0.037 (II) & 0.032 (II) \\
\hline 8. & $\mathrm{NH}_{4}^{+}\left(\mathrm{mg} \mathrm{N} \cdot \mathrm{dm}^{-3}\right)$ & 0.71 (II) & 0.78 (II) & 0.67 (II) \\
\hline 9. & $\mathrm{PO}_{4}^{3-}{ }_{\text {dis }}\left(\mathrm{mg} \mathrm{PO}_{4} \mathrm{dm}^{-3}\right)$ & 0.71 (IV) & 0.76 (IV) & 0.73 (IV) \\
\hline 10. & $P_{\text {tot. }}\left(\mathrm{mg} \mathrm{P} \cdot \mathrm{dm}^{-3}\right)$ & 0.62 (III) & 0.69 (III) & 0.59 (III) \\
\hline 11. & Saturation with $\mathrm{O}_{2}(\%)$ & $64.3(-)$ & $96.3(-)$ & $42.9(-)$ \\
\hline 12. & $\begin{array}{l}\text { Residue after ignition } \\
\left(\mathrm{mgdm}^{-3}\right)\end{array}$ & $176(-)$ & $208(-)$ & $193(-)$ \\
\hline
\end{tabular}

Explanation: I, II, III, IV, (-) - classification of values of examined indicators in accordance with the European Union Water Framework Directive(2000/60/EC) and not classified data - respectively

than in an acid medium. Apart from high acidity, excessive alkalinity of natural waters ( $\mathrm{pH}$ above 9 ) also has a clearly detrimental impact on organisms ${ }^{5,10,28-30,40,41,42,44,45}$. $\mathrm{pH}$ below 4.8 and above 9.2 are deleterious for aquatic organisms specially for fish.

The studied water river Odra Estuary had $\mathrm{pH}$ values in the neutral range -7.76 to 7.89 . According to the classification of the European Union Water Framework Directive, all water were classified as first class.

The aquatic ecosystems of the studied water River Odra Estuary experienced loss on ignition and non-corresponding values of COD-Mn according to the estimates, which were based on the measurements of "loss on drying" and "residue on ignition" in accordance with the methodology set out by ${ }^{35}$ and on the basis of COD-Mn results, which invariably matched III class water quality. In the water river Odra Estuary tested, considerable levels of organic matter, including reducing agents, were maintained throughout the year. The reasons for this state of affairs should also be sought in the river Odra estuary bed sediment, which is rich in organic matter ${ }^{1-5,7,10,27,28,30,32-34,36,40-42,44-47}$.

The most important elements involved in primary production are phosphorus and nitrogen ${ }^{1-5,7,10,27,28,30,32-34,36,40-42,44-47}$.

The presence of these substances determines the productivity of a water body, as well as its quality. One nutrient significantly affecting the quality of water is phosphorus $^{1-5,7,27,28,30,32-34,36,40-42,44,46,47}$.

It is the primary factor which constrains the development of phytoplankton and thus affects massive algal blooms. It can occur in water bodies in the form of inorganic phosphorus as well as dissolved organic forms ${ }^{1-5,7,27,28,30,32-34,36,42,46}$.

Phosphates, or the mineral forms of phosphorus, are best absorbed by organisms and play a huge role in the primary production of a reservoir ${ }^{33,34}$.

They are involved in the circulation of matter in any water body. Therefore, one should pay attention to phosphorus compounds in the demersal zone ${ }^{1-5,7,9,25,27,28,30,32-34,36,40-42,44,46,47}$.

Nitrogen occurs in the form of gas dissolved in the water, ammonium ions, nitrate and nitrite. In water river Odra Estuary, it is the main factor limiting the growth of organisms $^{1-5,7,9,10,25,27,28,30,32-34,36,40-42,44-47}$. 
The tests have demonstrated that water quality in the river Odra Estuary with regard to the tested indicators varied. By analyzing the average annual values, one can note that the $\mathrm{pH}, \mathrm{O}_{2 \text { diss }}$ and $\mathrm{NO}_{3}^{-}$concentration showed a relatively small variation in all the investigated river Odra estuary.

The suspended solids determination is particularly useful in the analysis of sewage and other waste waters and is as significant as BOD determination. It is used to evaluate the strength of domestic wastewaters and efficiency of treatment units. Suspended solids are not permissible in aquatic systems for many reasons.

Suspended solids containing much organic matter may cause putrefaction and consequently the stream may be devoid of dissolved oxygen. BOD is the amount of dissolved oxygen needed by aerobic biological organisms in a body of water to break down organic material present in given water sample at certain temperature over a specific time period and considered as an important water quality indicator ${ }^{11-16,37,22}$.

Total suspended solids in the Szczecin Lagoon, fell into the II class: The $\mathrm{P}_{\text {tot. }}$ concentrations in the surface layer of the water river Odra estuary was little differentiated, reaching the levels appropriate for the III quality class according to the classification of the European Union Water Framework Directive. The total phosphorus concentration was 0.48-0.69 $\mathrm{mgP} \mathrm{dm}{ }^{-3}$. The highest concentration of total phosphorus was recorded in Szczecin Lagoon-summer 2012 (about $0.69 \mathrm{mgP}$ $\left.\mathrm{dm}^{-3}\right)$.

The concentrations of $\mathrm{PO}_{4}^{3-}$ diss in the tested water River Odra Estuary varied more significantly-corresponding to water quality classes ranging from IV. The highest concentration of $\mathrm{PO}_{4}{ }^{3-}$ diss was recorded in river Odra Estuary-summer 2010 (about $0,87 \mathrm{mg} \mathrm{PO}_{4} \cdot \mathrm{dm}^{-3}$ ). An upswing in the concentration of phosphorus compounds in a river Odra Estuary may indicate a decreased amount of oxygen in the benthic waters and changes in their redox status leading to releasing phosphorus compounds accumulated in the bed sediment $^{1-5,7,9,10,25,27,28,30,32-34,36,40-42,44-47}$.

Increased levels of phosphorus are generally associated with increasing levels of eutrophication. The concentrations saturation with $\mathrm{O}_{2}$ was 42.9-96.3\%. The highest concentration of saturation with $\mathrm{O}_{2}$ was recorded in river Odra Estuarysummer 2012.

In the case of nitrogen compounds, nitrates and nitrites values for these indicators fell into the I and II class in all the surveyed river Odra Estuary in accordance with the classification of the European Union Water Framework Directive.

The indicator which proves high productivity of the river Odra estuary is the biochemical oxygen demand $\left(\mathrm{BOD}_{5}\right)$. The level of this indicator in the studied water Szczecin Lagoon was at level III. The highest concentration of biochemical oxygen demand was recorded in Szczecin Lagoon-summer 2008 and 2012 (about $5.8 \mathrm{mg} \mathrm{O}_{2} \cdot \mathrm{dm}^{-3}$ ).

The highest concentration of oxygen in the waters was found in the river Odra Estuary (about $8.3 \mathrm{mg} \mathrm{O}_{2} \cdot \mathrm{dm}^{-3}$ ). In the remaining water oxygen levels were similar (still in I class).

National sanitation foundation water quality index (NSF WQI): National Sanitation Foundation Water Quality Index (NSF WQI) used for rating of water quality in river
Odra estuary indicates that the quality of water is slightly polluted (WQI = 53.6). It is almost always endangered or deteriorated. The condition in it usually diverges from normal levels and the water is not able to protect or support plenty aquatic life. Phosphorus, dissolved oxygen, total alkalinity and total solids are the main factors responsible for determination of the lake water quality. These parameters need to be modified to maintain the quality of water for further use. NSF-WQI is an excellent management and general administrative tool in communicating water quality information. This index has been widely field tested and applied to data from a number of different geographical areas all over the world in order to calculate water quality index of various water bodies critical pollution parameters were considered ${ }^{11-17}$.

$$
\begin{gathered}
\mathrm{WQI}=0.1 \times\left[\Sigma \mathrm{WiQi}^{1,5}\right. \\
\mathrm{WQI}=51.4
\end{gathered}
$$

\section{Conclusion}

Assessment of the river Odra Estuary by WQI revealed that the lake is slightly polluted and could be placed in average quality class but the trend and hierarchy of the events threatens the lake.

Pollutants and pollution load is ever increasing and with the present pace of pollution load the lake water will not be suitable for large number aquatic organisms anymore and eventually will result in extinction of large number of plant and animal species in the near future. Dissolved oxygen (DO), phosphate, alkalinity and total suspended solids as dominant factors influencing lake water quality assessment should be managed. Finally an effective and responsible ecosystem based management measures should be taken to control pollution loads and save life of the river Odra Estuary.

The river Odra Estuary in the southern Baltic Sea is highly eutrophic coastal water that is affected by algae blooms during summer. To reach a good ecological status, as demanded by the EU Water Framework Directive, nutrient reductions in the river basin alone will not result in a sufficiently improved water quality. Several supporting internal measures are possible in theory to combat eutrophication, to remove nutrients and to improve ecosystem quality:

1. Dredging or capping of sediment

2. Enlarged reed belts and extended submersed macrophyte areas

3. Algae farms and finally

4. Enlarged natural mussel beds and mussel cultivation.

Accompanying researches as well as discussions with stakeholders are necessary to analyze pros and cons of internal measures and possibilities for implementation. Some of the criteria that have to be fulfilled, are:

- The measure must be ecologically justifiable. The ecosystem should not be disturbed or negatively changed by introducing invasive alien species for example. The Szczecin Lagoon is an important area for migrating birds and fish spawning. Large areas of the lagoon are FFH and NATURA 2000 sides. The measure has to be in agreement with the requirements of an environmental impact assessment.

- The measure must follow the regional spatial plan. The lagoon is characterized by different uses such as fishery, 
shipping and nature conservation. The measure should not compete with other traditional uses such as gillnet fisheries locating in the shallow areas of the lagoon. Economic loss must be prevented.

\section{REFERENCES}

1. P. Daniszewski, Int. Lett. Chem., Phys. Astron., 1, 6 (2012).

2. P. Daniszewski, Int. Lett. Chem., Phys. Astron., 1, 13 (2012).

3. P. Daniszewski, Int. Lett. Chem., Phys. Astron., 2, 42 (2012).

4. P. Daniszewski, Int. Lett. Chem., Phys. Astron., 2, 35 (2012).

5. P. Daniszewski and R. Konieczny, Int. Lett. Chem., Phys. Astron., 4, 91 (2013).

6. A. Kownacki, H. Soszka, D. Kudelska, T. Flejtuch, in eds. W. Geller, et al. Bioassessment of Polish Rivers Based on Macroinvertebrates, In: 11th Magdeburg Seminar on Waters in Central and Eastern Europe: Assessment, Protection, Management, Proceedings of the International Conference, 18-22 October, 2004 at UFZ-Bericht, 18, pp. 250-251 (2004).

7. N.L. Nemerov, Stream, Lake, Estuary and Ocean Pollution, Van Nostrand, Reinhold Company, New York, pp. 185-189 (1985).

8. G. Van Urk and B. de Vaate, in eds.: R. Kinzelbach and G. Friedrich, Ecological Studies in the Lower Rhine in The Netherlands; In: Biologie des Rheins. Limnologie Aktuell., vol. 1, pp. 131-145 (1990).

9. E. Bajkiewicz-Grabowska, J. Hydrol. Sci., 8, 63 (1981).

10. J.F. Wright, D. Moss, P.D. Armitage and M.T. Furse, Freshw. Biol., 14, 221 (1984)

11. O.S. Adefemi, S.S. Asaolu and O. Olaofe, Pak. Nut., 6, 657 (2007).

12. O.S. Adefemi and E.E. Awokunmi, African J. Environ. Sci. Technol., 4, 145 (2010).

13. J.E. Bollinger, L.J. Steinberg, M.J. Harrison, J.P. Crews, A.J. Englande, C. Velasco-Gonzales, L.E. White and W.J. George, Water Res., 33, 2627 (1999).

14. R.K. Borówka, in ed.: M. Kaczanowska, Srodowisko Geograficzne, Budowa geologiczna i Rozwój Krajobrazu, In: Przyroda Pomorza Zachodniego Wyd. Oficyna in Plus, Szczecin, pp. 40-56 (2002).

15. R.K. Borówka, A. Witkowski, J. Tomkowiak, M. Olas, K. Gusar and E. Liszkiewicz, in eds.: R.K. Borowka, Z. Mlynarczyk and A. Wojciechowski, Stratygraficzna i Przestrzenna Zmiennosc Litologiczna i Geochemiczna Osadów Wypelniajacych Zalew Szczecinski i Baseny przylegle, In: Ewolucja Geosystemow Nadmorskich Poludniowego Baltyku, Bogucki Wydawnictwo Naukowe, Poznan-Szczecin (1999).

16. D.A. Dunnette, J. Water Pollut. Control Fed., 51, 53 (1979).

17. M. Sharifinia, Z. Ramezanpour, J. Imanpour, A. Mahmoudifard and T. Rahmani, Int. J. Adv. Biol. Biomed. Res., 1, 302 (2013).

18. V. Simeonov, J.A. Stratis, C. Samara, G. Zachariadis, D. Voutsa, A. Anthemidis, M. Sofoniou and Th. Kouimtzis, Water Res., 37, 4119 (2003).

19. K.P. Singh, A. Malik, D. Mohan and S. Sinha, Water Res., 38, 3980 (2004).

20. A. Srivastava, R. Kr, V. Gupta, G. Agarwal, S. Srivastava and I. Singh, VSRD-TNTJ, 2, 119 (2011).

21. V.V. Sugunam, Turk. J. Fish. Aquat. Sci., 5, 35 (1995).

22. B. Wisniewski, in eds.: R.K. Borówka,Z. Mlynarczyk and A. Wojciechowski, Wspólczesne Zmiany Sredniego Poziomu Morza w Swinoujsciu, In: Ewolucja Geosystemów Nadmorskich Poludniowego Baltyku, Bogucki Wydawnictwo Naukowe, Poznan-Szczecin (1990).
23. B. Wisniewski, T. Wolski and H. Kowalewska-Kalkowska, Wybrane Przyklady Krótkoterminowej, Sezonowej i Dlugoterminowej Zmiennosci Wahan Poziomu Morza u Wybrzezy Zatoki Pomorskiej, Problemy Fizyczne Ekologii wód Naturalnych, Materialy, Konferencje, 36, Wyd. US, Szczecin, vol. 1, pp. 237-242 (1998).

24. T. Wolski, Ph.D. Thesis, Prady jeziora Dabie i ich zwiazek z rezimem hydrologicznym obszaru ujsciowego Odry, Instytut Nauk o Morzu, Uniwersytet Szczecinski, Szczecin, Poland (2005).

25. E. Bécares, Limnetica, 25, 143 (2006).

26. Z. Chudecki and L. Duda, Pol. Soil Sci., 4, 145 (1971).

27. P. Daniszewski, Int. Lett. Chem., Phys. Astron., 2, 46 (2012).

28. T. Fleituch, H. Soszka, D. Kudelska and A. Kownacki, Arch. Hydrobiol., Suppl.141/3, 225 (2002).

29. Z. Kajak, Hydrobiology-limnology, Inland Water Ecosystems, PWN, Warsaw, pp. 355 (1998).

30. Z. Kajak, Ekol. Pol., 31, 495 (1983).

31. A. Kownacki and H. Soszka, Guidelines for the Evaluation of Status of Rivers on the Basis of Macroinvertebrates and for Intakes of Macroinvertebrate Samples in Lakes, Warsaw, p. 51 (2004).

32. J. Kubiak, Acta Sci. Pol. Piscaria, 2, 141 (2003).

33. W. Lampert and U. Sommer, Ecology of Inland Waters, Scientific Publishing PWN, Warsaw, pp. 415 (2001).

34. A. Lelek, in ed.: D.P. Dodge, The Rhine River and some on its Tributaries Under Human Impact in the Last Two Centuries; In: Proceedings of International Large River Symposium, Canadian Special Publication of Fisheries and Aquatic Sciences, vol. 106, pp. 469-487 (1989).

35. A. Macioszczyk, Hydrochemistry, Warsaw, pp. 475 (1987).

36. P. Psenner, B. Boström, M. Dinka, K. Pettersson, R. Pucsko and M. Sager, Arch. Hydrobiol. Beih. Ergebn. Limnol., 30, 83 (1988).

37. A. Ikem, N.O. Egiebor and K. Nyavor, Soil Pollut., 149, 51 (2003).

38. D.E. Lerda and C.H. Prosperi, Water Res., 30, 819 (1996).

39. Directive 2000/60/EC of the European Parliament and of the Council of 23 October 2000 Establishing a Framework for Community Action in the Field of Water Policy, Off. J. Eur. Commun., L327, 22 December 2000

40. C. Richards, G.E. Host and J.W. Arthur, Freshw. Biol., 29, 285 (1993).

41. M. Søndergaard, K.D. Wolter and W. Ripl, in eds.: M.R. Perow and A.J. Davy, Chemical Treatment of Water and Sediments with Special Reference to Lakes, In: Handbook of Ecological Restoration, Cambridge University Press, Cambridge, pp. 184-205 (2002).

42. F. Garcia-Criado, A. Tomé, F.J. Vega and C. Antolin, Hydrobiologia, 394, 209 (1999).

43. J. Janczak, Atlas Polish Lakes pp. 92-95 (1996).

44. J. Trojanowski and J. Bruski, Baltic Coastal Zone, 4, 53 (2000).

45. B. Zdanowski, Ekol. Polska, 31, 287 (1983).

46. A. Mudroch, J.M. Azcue and P. Mudroch, Physico-Chemical Analysis of Aquatic Sediments. Lewis Publishers Boca Raton, New York, London, Tokyo (1997).

47. J. Trojanowski, J. Antonowicz, M. Król and J. Bruski, Soc., 1, 131 (2001). 